\title{
Remediative Capacity of Crude Oil-polluted Soil After Exposure to Poultry Manure and Phosphate Minerals
}

\section{${ }^{* 1}$ EVBUOMWAN, NO; ${ }^{1}$ OVIASOGIE, FE; ${ }^{2}$ OVIASOGIE, PO; ${ }^{3}$ IKHAJIAGBE, B}

\author{
${ }^{I}$ Department of Microbiology, Faculty of Life Sciences, University of Benin, Benin City, Nigeria \\ ${ }^{2}$ Soils and Land Management Division, Nigerian Institute for Oil Palm Research (NIFOR), P.M.B 1030, Benin City, Nigeria. \\ ${ }^{3}$ Department of Plant Biology and Biotechnology, University of Benin, Benin City, Nigeria. \\ *Corresponding Author Email: nosamwan86@gmail.com
}

\begin{abstract}
This study investigated the impact of two soil amendments (poultry manure and phosphate rock minerals) on the intrinsic remediation capacity of a crude oil-contaminated soil. Well drained top soil $(0-10 \mathrm{~cm})$ was polluted with crude oil at the rate of $0.02 \mathrm{~mL} / \mathrm{g}$ of soil and amended with phosphate rock $(\mathrm{PR})$ and poultry manure in three batches at $20 \mathrm{~g}, 30 \mathrm{~g}, 40 \mathrm{~g}$ and $50 \mathrm{~g}$ per $500 \mathrm{~g}$ of soil respectively in plastic bowls. Soil samples were collected from plastic bowls for physicochemical, microbiological, biodegradability and total hydrocarbon contents analyses. Results revealed improvement in physicochemical parameters in $\mathrm{pH}$, total nitrogen and phosphorus of 7.00-7.50, 0.12-0.22 \%, and 13.20 $65.42 \mathrm{mg} / 100 \mathrm{~g}$ after remediation against $4.30,0.02 \%$ and $6.05 \mathrm{mg} / 100 \mathrm{~g}$ recorded in day zero respectively. Bacillus subtilis (2.01), Pseudomonas aeruginosa (1.94), Mucor mucedo (2.47) and Penicillium notatum (2.43) had high biodegradation potential (NTU). The remediation efficiency of total hydrocarbon content after remediation was enhanced by two factors; increased concentrations of amendments of $50 \mathrm{~g}$ of poultry manure $(4.62 \mathrm{mg} / 100 \mathrm{~g} ; 66.45 \%)$ and phosphate rock $(0.33 \mathrm{mg} / 100 \mathrm{~g} ; 97.60 \%)$; And by application of combined amendments of both poultry manure and phosphate rock $(0.19 \mathrm{mg} / 100 \mathrm{~g} ; 98.62 \%)$ compared to control $(8.46 \mathrm{mg} / 100 \mathrm{~g} ; 38.56 \%)$. Poultry manure and phosphate rock amendments enhance bioremediation efficiency in clean-up of crude oil polluted site and obviously a contamination free environment is a healthy and safe environment for all.
\end{abstract}

\section{DOI: https://dx.doi.org/10.4314/jasem.v23i10.20}

Copyright: Copyright (C) 2019 Evbuomwan et al. This is an open access article distributed under the Creative Commons Attribution License (CCL), which permits unrestricted use, distribution, and reproduction in any medium, provided the original work is properly cited.

Dates: Received: 01 September 2019; Revised: 21 October 2019; 27 October 2019

Keywords: Bioremediation, Poultry manure, Phosphate mineral, Hydrocarbon content

The economic benefits and uses of crude oil are enormous to mention nevertheless, the contamination caused by its spills has drastically impaired biological and ecological functions in the ecosystem. Crude oil pollution has generated great toxic danger on account of their spill in the environment. The toxic discharges of crude oil or petroleum products are enormous, based on their constituent, magnitude, ecological factors and the biological component in the contaminated environment Crude oil is a complex mixture of aliphatic, alicyclic, aromatic hydrocarbons, and smaller proportions of heteroatom compounds (sulfur, nitrogen, and oxygen) and also organometallic complexes of nickel and vanadium in much smaller proportions compared to other constituents; however these organometallic compounds are problematic during crude oil refining (Head et al., 2003). Leaks and accidental spills take place frequently in the exploration, production, refining, transport, and storage of petroleum and petroleum products. Poultry litters are used as soil fertilizers due to its high quantity of nitrogen and reasonable amount of phosphorus as nutrients for microbes. The microbial, chemical, and physical composition makes it a suitable co-substrate and nutrient springs for potential uses in bioremediation of crude oil contaminated soil (Ezekoye et al., 2017). Phosphate rock (PR) is a generally used to describe naturally occurring mineral compound with high content of phosphate minerals $\left(\mathrm{P}_{2} 0_{5}\right)$ (Chien et al., 2010). Many sources of PR are rich in free carbonates, such as calcite $\left(\mathrm{CaCO}_{3}\right)$ and dolomite $\left(\mathrm{CaMg}\left(\mathrm{CO}_{3}\right)_{2}\right)$, which provide Calcium and Magnesium for dealing with soil acidity (Chien, 1977). The presence of carbonates and magnesium $(\mathrm{Mg})$ ) minerals are suitable for plant nutrition and soil amendment. PRs which is phosphor-composting is environmentally beneficial as organic manures that are readily used or are a viable alternative to chemical fertilizers (Mugwira et al., 2002). Remediating a site polluted with hazardous waste materials is a very tedious and complex procedure; and this usually involves a systematic, step-by-step problem solving approach. Bioremediation of contaminated soils is currently regarded as one of the most successful ways to clean up contaminated sites, particularly because it is adjudged eco-friendly (Ikhajiagbe et al., 2014). Soil 
microorganisms are significant in the ecosystem; they adjust energy flow, cycle nutrients and promote it availability for growth and development of agricultural crops, maintain ecosystem, organic matter transfer and intrinsic bioremediation of contaminants as a food substrate. Bioremediation which is the use of natural substances (poultry manure, phosphate rock minerals and microorganisms) in the recovery of crude oil polluted soil is a generally accepted form of remediation rather than the introduction of chemicals. This study is therefore aimed at examining the impact of two soil amendments (poultry manure and phosphate rock minerals) on the intrinsic remediation capacity of a crude oil-polluted soil.

\section{MATERIALS AND METHOD}

Well drained topsoil $(0-10 \mathrm{~cm})$ was obtained from a farmland, and phosphate rock (PR)used for the study was obtained from National Institute for Oil Palm Research, Benin City, Edo State. Dry poultry manure (PM) was collected from the University of Benin poultry farmand was pooled together to obtain a composites sample. The crude oil (Forcados Blend) was collected from Shell Petroleum Development Company Forcadoes Warri South West, Delta State.

Experimental design: Crude oil (10mL) was measured and poured unto $500 \mathrm{~g}$ of soil and presented in 3 groups. The first group (Group A) which were amended with poultry manure (PM) was subdivided into 4 other groups on the basis of quantity of manure added to soil. The second group B consisted of oilpolluted soil amended with phosphate rock (PR). The third group $\mathrm{C}$ consisted of soil amendments with a consortium of both manure and rock. Generally, the treatment designations were as follows;

A1: oil-polluted soil with $20 \mathrm{~g}$ of poultry manure, A2: oil-polluted soil with $30 \mathrm{~g}$ of poultry manure, A3: oilpolluted soil with $40 \mathrm{~g}$ of poultry manure, A4: oilpolluted soil with $50 \mathrm{~g}$ of poultry manure, B1: oilpolluted soil with $20 \mathrm{~g}$ of phosphate rock, B2:oilpolluted soil with $30 \mathrm{~g}$ of phosphate rock, B3: oilpolluted soil with $40 \mathrm{~g}$ of phosphate rock, B4:oilpolluted soil with $50 \mathrm{~g}$ of phosphate rock, C1:oilpolluted soil with $20 \mathrm{~g}$ of both poultry manure and phosphate rock, C2:oil-polluted soil with $30 \mathrm{~g}$ of both poultry manure and phosphate rock, C3: oil-polluted soil with $40 \mathrm{~g}$ of both poultry manure and phosphate rock, C4:oil-polluted soil treated with $50 \mathrm{~g}$ of both poultry manure and phosphate rock. Control soil was unamended oil-polluted soil.

Research process description: The amended oilpolluted soils were exposed, kept in a screen house and observed for a minimum of a month. Thereafter soil was assayed for culturable bacteria and fungi (Cheesbrough, 2000). Soil physiochemical analysis was also carried out according to the methods described by APHA (2008).

Bacteria and fungi enumeration: Bacteria and fungi analyses were done using the methods of Cheesbrough (2000); Chikere et al. (2009) and Nwadinigwe and Onyeidu (2012).

Characterization and identification of bacterial isolates: Isolates with distinct colony characteristics were sub-cultured aseptically using wire loop and streaking on the surface of freshly prepared NA plates and incubated at $37^{\circ} \mathrm{C}$ for $24-48$ hours. The discrete colonies were identified based on cultural and morphological characteristic such as size, colour, margin, shape and Gram staining reaction. Biochemical test, such as Indole, Methyl red, citrate utilization, catalase, oxidase, nitrate reduction, urease, motility test and sugar fermentation test were carried out using standard protocols (Cheesbrough, 2000; Chikereet al., 2009; Joonu and Averal, 2012).

Characterization and identification of fungal isolates: Isolates with observable distinct colony characteristics were sub-cultured aseptically using wire loop and streaking on the surface of freshly prepared PDA and incubated at $28 \pm 11^{\circ} \mathrm{C}$ for 3-7 day. Pure fungal isolates were characterized on the basis of cultural and morphological characteristics which include spore formation, color, margin, mycelia and other fruiting bodies. Slides were prepared from pure cultures and viewed under motic light microscope at $40 \mathrm{X}$ magnification after adding few drops of lactophenol blue for mycelia (Cheesbrough, 2000).

Percentage prevalence of bacteria and fungi isolates: The percentage prevalence $(\% \mathrm{P})$ of bacteria and fungi isolates from all the treatments were carried out after morphological and biochemical characterization. The number of a bacterium and fungal species isolated were recorded according to their population in the various treatments.

$\% P=\frac{\text { Total no. of an isolate in treatments }}{\text { Sum of all isolates }} \times 100$

In-vitro biodegradability Studies: In-vitro biodegradability studies were carried out by inoculating a loop full of pure colony of discreet isolates from freshly prepared nutrient agar plates into test tubes containing $10 \mathrm{ml}$ of mineral salt medium (MSM) broth and $0.2 \% \mathrm{w} / \mathrm{w}$ of crude oil. After which, the culture were agitated at $150 \mathrm{rpm}$ and incubated at $27^{\circ} \mathrm{C}$ for 35 days. At 5 days interval during the 
incubation period, $4 \mathrm{ml}$ of the culture was withdrawn and the turbidity readings were determined using UV spectrophotometer at optical density of $600 \mathrm{~nm}$ wavelength (Bujang et al., 2013; Ataikiruet al., 2017; Gulati and Mehta, 2017).

Determination of physicochemical parameters: Physicochemical parameters such as $\mathrm{pH}$, nitrogen, phosphate, calcium, magnesium and potassium and total hydrocarbon carbon (THC) were determined using methods from APHA (2008). The percent remediation efficiency ( $\% \mathrm{RE})$ of total hydrocarbon utilization was calculated.

$$
\% R E=\frac{\text { Initial THC }- \text { Final THC }}{\text { Initial THC }} \times 100
$$

Statistical analysis: Analysis of variance was done using SPSS $20^{\circledR}$ and PAST ${ }^{\circledR}$. Means were separated at
$95 \%$ confidence limit by using least significant differences.

\section{RESULTS AND DISCUSSION}

The poultry manure in this study had the highest total heterotrophic bacteria count (THBC) and total heterotrophic fungi count (THFC) (Table 1). This is in accordance with Ameh and Kawo, (2017) result were it was reported that the difference in the count was due to $\mathrm{pH}$ and organic matter content which aid the proliferation of microorganisms. The THBC and THFC of uncontaminated soil recorded higher counts than contaminated soil THBC and THFC (Table 1). Ataikiruet al. (2017) stated that the variation in microbial counts is the simplest method of monitoring microbial activities in bioremediation.

\begin{tabular}{lll}
\multicolumn{3}{c}{ Table 1: Mean total heterotrophic counts of samples used for remediation } \\
\hline Samples & $\begin{array}{l}\text { Total Heterotrophic Bacterial } \\
\text { Counts (THBC) } \mathbf{x 1 0}(\mathbf{c f u} / \mathbf{g})\end{array}$ & $\begin{array}{l}\text { Total Heterotrophic Fungal Counts } \\
\text { (THFC) } \mathbf{1 0} \text { (10 } \mathbf{( c f u} / \mathbf{g})\end{array}$ \\
\hline Poultry Manure (PM) & $195.20^{\mathrm{b}} \pm 4.30$ & $442.40^{\mathrm{b}} \pm 13.42$ \\
Phosphate Rock (PR) & $38.00^{\mathrm{a}} \pm 1.58$ & $53.60^{\mathrm{a}} \pm 10.71$ \\
Soil(uncontaminated) & $78.40^{\mathrm{a}} \pm 2.31$ & $67.00^{\mathrm{a}} \pm 7.98$ \\
Control(contaminated) & $19.78^{\mathrm{a}} \pm 7.33$ & $50.20^{\mathrm{a}} \pm 11.62$ \\
\hline
\end{tabular}

$\boldsymbol{a}$ and $\boldsymbol{b}$ means level of significant difference; similar alphabet superscripts do not differ significantly $(p>0.05)$ from each other

\begin{tabular}{ccccccc}
\multicolumn{7}{c}{ *Table 2: Physicochemical parameter analysis of soil and amended contaminated soil } \\
\hline SD & $\mathrm{pH}$ & $\mathrm{TN}$ & $\mathrm{P}(\mathrm{mg} / 100 \mathrm{~g})$ & $\mathrm{Ca}(\mathrm{mg} / 100 \mathrm{~g})$ & $\mathrm{Mg}(\mathrm{mg} / 100 \mathrm{~g})$ & $\mathrm{K}(\mathrm{mg} / 100 \mathrm{~g})$ \\
\hline UCS & $6.20 \pm 0.00$ & $0.05 \pm 0.00$ & $12.15 \pm 0.00$ & $0.39 \pm 0.00$ & $7.68 \pm 0.00$ & $1.52 \pm 0.00$ \\
\hline CTD1 & $4.3 \pm 0.00$ & $0.02 \pm 0.00$ & $6.05 \pm 0.00$ & $6.00 \pm 0.00$ & $1.04 \pm 0.00$ & $0.23 \pm 0.00$ \\
\hline CTA & $5.10 \pm 0.00$ & $0.12 \pm 0.00$ & $7.35 \pm 0.00$ & $10.40 \pm 0.00$ & $2.05 \pm 0.00$ & $0.35 \pm 0.00$ \\
\hline TA1 & $7.00 \pm 0.12$ & $0.24 \pm 0.01$ & $9.71 \pm 0.01$ & $11.28 \pm 0.01$ & $2.24 \pm 0.01$ & $0.86 \pm 0.01$ \\
\hline TA2 & $7.00 \pm 0.06$ & $0.25 \pm 0.01$ & $13.20 \pm 0.06$ & $13.52 \pm 0.01$ & $2.80 \pm 0.01$ & $1.09 \pm 0.01$ \\
\hline TA3 & $7.07 \pm 0.09$ & $0.33 \pm 0.01$ & $14.55 \pm 0.01$ & $13.68 \pm 0.01$ & $3.18 \pm 0.01$ & $1.39 \pm 0.01$ \\
\hline TA4 & $7.30 \pm 0.06$ & $0.37 \pm 0.01$ & $22.11 \pm 0.01$ & $16.48 \pm 0.01$ & $3.28 \pm 0.01$ & $1.52 \pm 0.01$ \\
\hline TB1 & $7.20 \pm 0.06$ & $0.20 \pm 0.01$ & $59.22 \pm 0.01$ & $18.56 \pm 0.01$ & $0.81 \pm 0.01$ & $0.49 \pm 0.01$ \\
\hline TB2 & $7.30 \pm 0.06$ & $0.21 \pm 0.01$ & $62.42 \pm 0.01$ & $20.00 \pm 0.12$ & $0.90 \pm 0.01$ & $0.57 \pm 0.01$ \\
\hline TB3 & $7.20 \pm 0.06$ & $0.21 \pm 0.01$ & $63.91 \pm 0.01$ & $20.72 \pm 0.01$ & $1.10 \pm 0.06$ & $0.59 \pm 0.01$ \\
\hline TB4 & $7.20 \pm 0.06$ & $0.22 \pm 0.01$ & $65.97 \pm 0.01$ & $25.76 \pm 0.01$ & $1.12 \pm 0.01$ & $0.62 \pm 0.01$ \\
\hline TC1 & $7.50 \pm 0.06$ & $0.15 \pm 0.01$ & $43.90 \pm 0.06$ & $16.32 \pm 0.01$ & $1.60 \pm 0.01$ & $7.50 \pm 0.06$ \\
\hline TC2 & $7.27 \pm 0.09$ & $0.17 \pm 0.01$ & $46.64 \pm 0.01$ & $20.56 \pm 0.01$ & $1.68 \pm 0.01$ & $7.30 \pm 0.06$ \\
\hline TC3 & $7.20 \pm 0.06$ & $0.18 \pm 0.01$ & $60.71 \pm 0.01$ & $23.12 \pm 0.01$ & $2.32 \pm 0.01$ & $7.10 \pm 0.06$ \\
\hline TC4 & $7.10 \pm 0.06$ & $0.19 \pm 0.01$ & $62.42 \pm 0.01$ & $24.00 \pm 0.01$ & $2.40 \pm 0.01$ & $7.10 \pm 0.06$ \\
\hline
\end{tabular}

*SD sample description, Mean and S.E of results: Keys: UCS = Uncontaminated soil, $\boldsymbol{C T D 1}=$ Control day one, $\boldsymbol{C T \boldsymbol { A }}=$ Control after remediation, $\boldsymbol{T} \boldsymbol{A}=$ Poultry manure amended contaminated soil, $\boldsymbol{T B}=$ Phosphate rock amended soil, $\boldsymbol{T} \boldsymbol{C}=$ Poultry manure and phosphate rock amended contaminated soil.

The physicochemical parameters analyzed revealed that $\mathrm{pH}$ of the uncontaminated and the contaminated soil was acidic as against the amended contaminated soil which was alkaline (Table 2). Crude oil introduction has reduced the $\mathrm{pH}$ and addition of soil amendments raised the $\mathrm{pH}$ to neutral/alkaline for active microbial catabolic capacity. These nutrients $\mathrm{N}$, $\mathrm{P}, \mathrm{K}, \mathrm{Ca}, \mathrm{K}$ and $\mathrm{Mg}$ were all influenced by the addition of poultry manure and phosphate rock to crude oil polluted soils which resulted in their increase, which stimulated microbial growth and allowed microbes to synthesize the necessary enzymes needed to break down the petroleum hydrocarbon contaminants (Vidali, 2001; Obasi et al., 2013). Factors that affect populations and activities of microorganisms in soil may significantly affect soil characteristics and environmental quality (Oviasogie and Oviasogie, 2014). Total heterotrophic bacteria count (THBC) and total heterotrophic fungi count (THFC) (Figure 1 and 2) as well as the hydrocarbon utilizing bacteria count 
HUBC (Figure 3) and hydrocarbon utilizing fungi (HUFC) count (Figure 4) increased in all the treatments over control resulting in consistent level of degradation during remediation as a result of the poultry manure and phosphate rock content used singly and in combination.
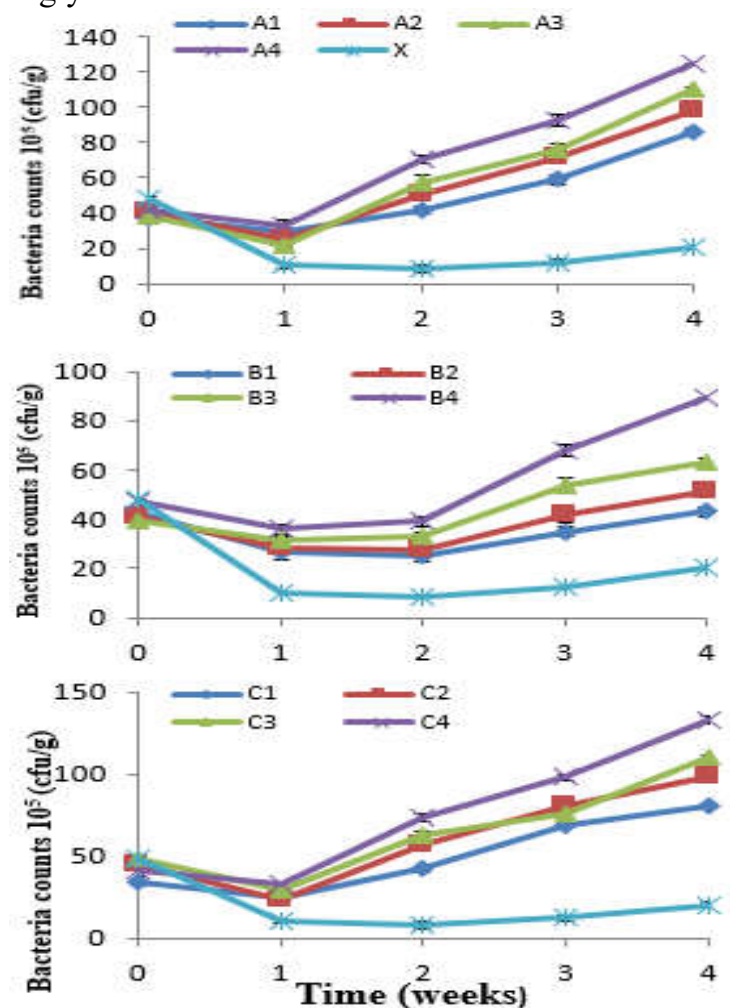

Fig 1: Total heterotrophic bacteria count for crude oil contaminated soil treated with various amendments

Key: A1: contaminated soil with $20 \mathrm{~g}$ of poultry manure, A2: contaminated soil with $30 \mathrm{~g}$ of poultry manure, A3: contaminated soil with $40 \mathrm{~g}$ of poultry manure, A4: contaminated soil with $50 \mathrm{~g}$ of poultry manure, B1: contaminated soil with $20 \mathrm{~g}$ of phosphate rock, B2: contaminated soil with $30 \mathrm{~g}$ of phosphate rock, B3. contaminated soil with $40 \mathrm{~g}$ of phosphate rock, B4: contaminated soil with $50 \mathrm{~g}$ of phosphate rock, C1: contaminated soil with $20 \mathrm{~g}$ of both poultry manure and phosphate rock, C2: contaminated soil with $30 \mathrm{~g}$ of both poultry manure and phosphate rock, C3: contaminated soil with $40 \mathrm{~g}$ of both poultry manure and phosphate rock, C4: contaminated soil treated with $50 \mathrm{~g}$ of both poultry manure and phosphate rock.

However, the combined treatment of poultry manure and phosphate rock resulted in increased population of HUBC and HUFC all through. Margesin et al. (2000) in their research work stated that the increase in the numbers of microorganisms demonstrated how indigenous soil microorganisms are able to adapt to new substrates (crude oil) for growth which in turn reduce toxic substances in the environment.

A total of ten (10) bacterial and five (5) fungi isolates with their frequency and percentage occurrence observed in Table 3wereEnterobacteraerogenes, Escherichia coli, Clostridium xylanolyticum,
Salmonella typhimurium, Staphylococcus aureus, Staphylococcus epidermidis, Streptococcus pyrogenes, Bacillus subtilis, Pseudomonas aeruginosa, Proteus mirabilis and Aspergillus flavus, Aspergillus tarmari, Aspergilus niger, Mucor mucedoand Penicillium notatum.

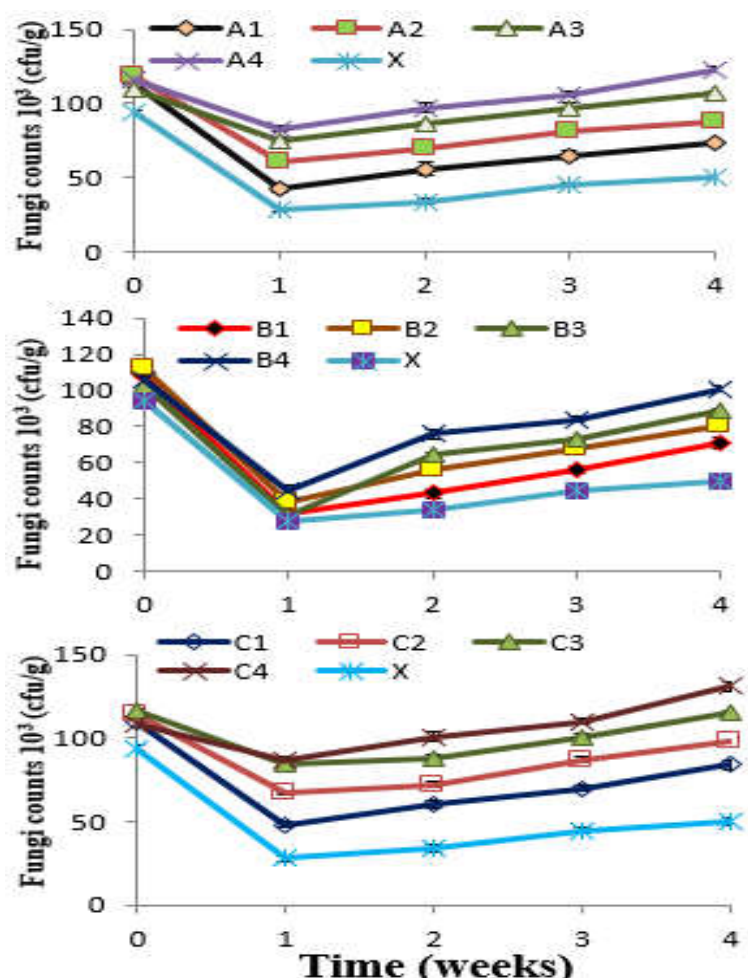

Fig 2: Total heterotrophic fungi count for crude oil contaminated soil treated with various amendments.

Key: A1: contaminated soil with $20 \mathrm{~g}$ of poultry manure, A2: contaminated soil with $30 \mathrm{~g}$ of poultry manure, A3: contaminated soil with $40 \mathrm{~g}$ of poultry manure, A4: contaminated soil with $50 \mathrm{~g}$ of poultry manure, B1: contaminated soil with $20 \mathrm{~g}$ of phosphate rock, B2: contaminated soil with $30 \mathrm{~g}$ of phosphate rock, B3: contaminated soil with $40 \mathrm{~g}$ of phosphate rock, B4: contaminated soil with $50 \mathrm{~g}$ of phosphate rock, C1: contaminated soil with $20 \mathrm{~g}$ of both poultry manure and phosphate rock, C2: contaminated soil with $30 \mathrm{~g}$ of both poultry manure and phosphate rock, C3: contaminated soil with $40 \mathrm{~g}$ of both poultry manure and phosphate rock, C4: contaminated soil with $50 \mathrm{~g}$ of both poultry manure and phosphate rock.

Chikere and Ekwuabu, (2014) previously reported that microorganisms are oil and hydrocarbon degrading microbes. Microbes are in syntrophic association in crude oil contaminated environment (Okoh, 2006) and release secondary substrates that support the growth and activities of other microbes after metabolizing the organic compounds in the crude oil (Banat, 2004). This enhances the solubility, availability and biodegradation of petroleum hydrocarbons (Wong et al., 2004). The in-vitro biodegradability studies of microbial isolates showed that microorganism biodegrade crude oil. Bacillus and Mucor species were the most predominant crude oil degrading bacteria and 
fungi isolates owing to their high environmental tolerance to crude oil pollution. This is however attributed to the fact that they form spores, which aids microorganisms to survive harsh conditions (Okafor et al., 2016).
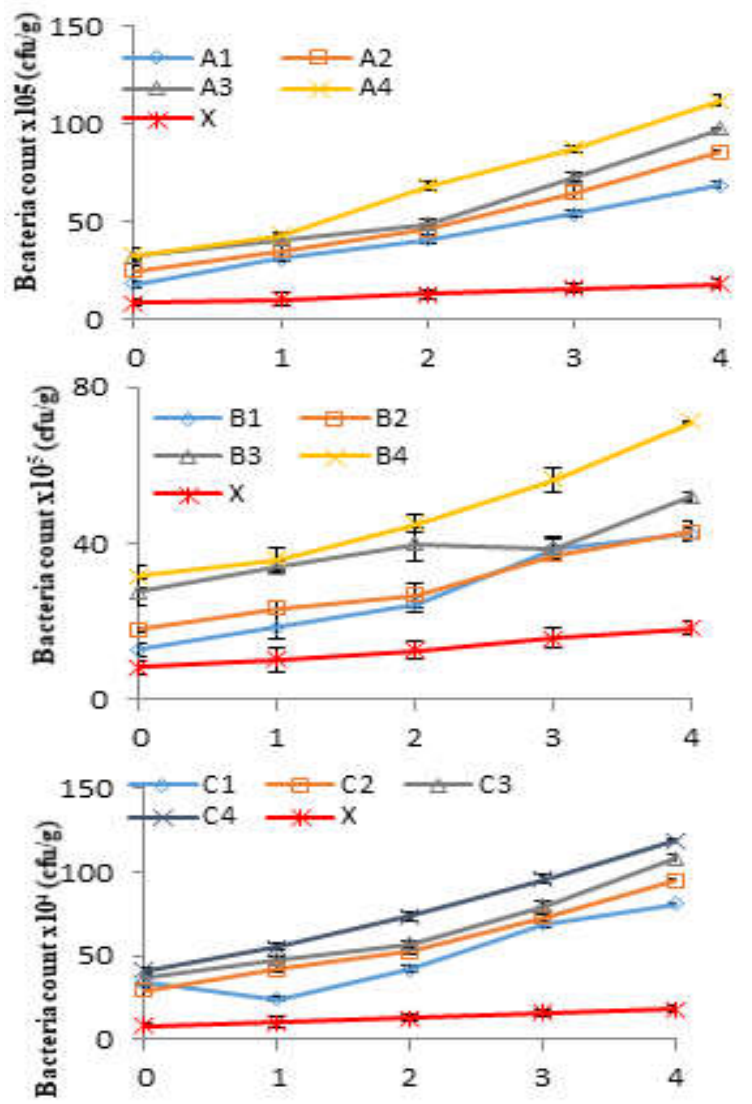

Time (weeks)

Fig 3: Hydrocarbon utilizing bacteria count (HUBC) of crude oil contaminated soil treated with various amendments

Key: A1: contaminated soil with $20 \mathrm{~g}$ of poultry manure, A2. contaminated soil with $30 \mathrm{~g}$ of poultry manure, A3: contaminated soil with $40 \mathrm{~g}$ of poultry manure, A4: contaminated soil with $50 \mathrm{~g}$ of poultry manure, B1: contaminated soil with $20 \mathrm{~g}$ of phosphate rock, B2: contaminated soil with $30 \mathrm{~g}$ of phosphate rock, B3: contaminated soil with $40 \mathrm{~g}$ of phosphate rock, B4: contaminated soil with $50 \mathrm{~g}$ of phosphate rock, C1: contaminated soil with $20 \mathrm{~g}$ of both poultry manure and phosphate rock, C2: contaminated soil with $30 \mathrm{~g}$ of both poultry manure and phosphate rock, C3: contaminated soil with $40 \mathrm{~g}$ of both poultry manure and phosphate rock, C4: contaminated soil with $50 \mathrm{~g}$ of both poultry manure and phosphate rock.

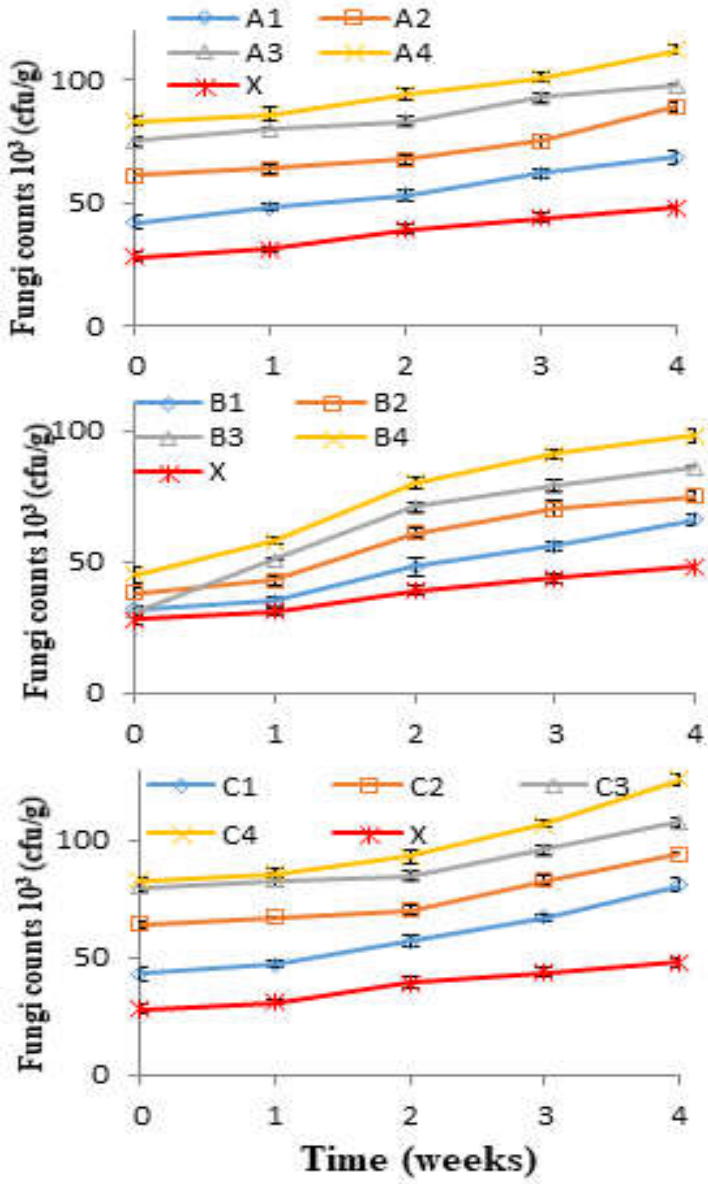

Fig 4: Hydrocarbon utilizing fungi count (HUFC) of crude oil contaminated soil treated with various amendments.

Key: A1: contaminated soil with $20 \mathrm{~g}$ of poultry manure, A2: contaminated soil with $30 \mathrm{~g}$ of poultry manure, A3: contaminated soil with $40 \mathrm{~g}$ of poultry manure, A4: contaminated soil with $50 \mathrm{~g}$ of poultry manure, B1: contaminated soil with $20 \mathrm{~g}$ of phosphate rock, B2: contaminated soil with $30 \mathrm{~g}$ of phosphate rock, B3: contaminated soil with $40 \mathrm{~g}$ of phosphate rock, B4: contaminated soil with $50 \mathrm{~g}$ of phosphate rock, C1: contaminated soil with $20 \mathrm{~g}$ of both poultry manure and phosphate rock, C2: contaminated soil with $30 \mathrm{~g}$ of both poultry manure and phosphate rock, C3: contaminated soil with $40 \mathrm{~g}$ of both poultry manure and phosphate rock, C4: contaminated soil with $50 \mathrm{~g}$ of both poultry manure and phosphate rock.

Table 3: Percentage prevalence of bacteria and fungi isolates in treated contaminated soil

\begin{tabular}{|c|c|c|c|c|c|}
\hline Isolates (Bacteria) & Frequency & $\begin{array}{l}\text { Percentage } \\
(\%)\end{array}$ & Isolates (Fungi) & Frequency & $\begin{array}{l}\text { Percentage } \\
(\%)\end{array}$ \\
\hline Bacillus subtilis & 8 & 21.05 & Aspergillus tormaxii & 3 & 12.50 \\
\hline Pseudomonas aexusinasa & 6 & 15.79 & Aspexgillus flanus & 3 & 12.50 \\
\hline Extercobactex asxogeness & 5 & 13.16 & dopergillus vigex & 9 & 37.50 \\
\hline Staphylococcus epideronidis & 5 & 13.16 & Mucor buceda. & 3 & 12.50 \\
\hline Proteus mirabilis & 3 & 7.89 & Pericillium notatum & 6 & 25.00 \\
\hline Streptococcus pwogene & 3 & 7.89 & & & \\
\hline Clastridium xolamoleticum & 3 & 7.89 & & & \\
\hline Salmonella tophiwswium & 2 & 5.26 & & & \\
\hline Staphylococcus avxeus. & 2 & 5.26 & & & \\
\hline Escherichia coli & 1 & 2.63 & & & \\
\hline Sum of all isolates & 38 & 100 & Sum of all isolates & 24 & 100 \\
\hline
\end{tabular}

EVBUOMWAN, NO; OVIASOGIE, FE; OVIASOGIE, PO; IKHAJIAGBE, B 
Fungi species have been reported to be good producers of cellulase, the enzyme responsible for the breakdown of cellulose in petroleum products (Wong et al., 2004) for more microbial hydrocarbon up-take. The total hydrocarbon content (THC) (figure 5) revealed that initial remediation (day 1) had the highest value of $13.77 \pm 0.00 \mathrm{mg} / 100$ g. After remediation, the THC $(\mathrm{mg} / 100 \mathrm{~g})$ reduced across the treatments $(5.57 \pm 0.01$ to $0.19 \pm 0.01)$ and control $(8.46 \pm 0.00)$. THC $(\mathrm{mg} / 100 \mathrm{~g})$ revealed that the treatment consortium of $50 \mathrm{~g}$ of both poultry manure and phosphate rock $(0.19 \pm 0.01)$ used as amendment recorded the least level of THC residual compare to the control $(8.46 \pm 0.00)$ with the highest THC residual level. The remediation efficiency (percentage) of total hydrocarbon content (THC) observed from Figure 5 after remediation revealed that there was a great reduction across the treatments ranging from $98.62 \%$ to $59.55 \%$ and the control by $38.56 \%$.

*Table 4: In-vitro biodegradability potential of bacterial isolates turbidity readings

\begin{tabular}{|c|c|c|c|c|c|}
\hline & \multicolumn{5}{|c|}{ Bioremediation Duration (Days) (NTU) } \\
\hline & 0 & 10 & 15 & 20 & 25 \\
\hline S. epideromidir & $1.23 \pm 0.3 \quad 1.37 \pm 0.4$ & $1.41 \pm 0.8$ & $1.60 \pm 0.5$ & $1.71 \pm 0.1$ & $1.86 \pm 0.1 \quad 1.87 \pm 0.5$ \\
\hline S. auxeus. & $1.11 \pm 0.7 \quad 1.18 \pm 0.4$ & $1.21 \pm 0.3$ & $1.31 \pm 0.1$ & $1.46 \pm 0.1$ & $1.56 \pm 0.5 \quad 1.86 \pm 0.1$ \\
\hline B. subtilis. & $1.46 \pm 0.3 \quad 1.50 \pm 0.8$ & $1.5 \mathrm{l} \pm 0.3$ & $1.59 \pm 0.1$ & $1.60 \pm 0.1$ & $1.91 \pm 0.42 .01 \pm 0.1$ \\
\hline P. asxuginosa & $1.51 \pm 0.8 \quad 1.30 \pm 0.4$ & $1.43 \pm 0.5$ & $1.56 \pm 0.5$ & $1.59 \pm 0.3$ & $1.70 \pm 0.5 \quad 1.94 \pm 0.1$ \\
\hline S. pwogentes & $\begin{array}{lll}1.27 \pm 0.1 & 1.29 \pm 0.4\end{array}$ & $1.33 \pm 0.1$ & $1.60 \pm 0.8$ & $1.70 \pm 0.1$ & $\begin{array}{lll}1.70 \pm 0.5 & 1.88 \pm 0.8\end{array}$ \\
\hline S. tophiwswium & $1.28 \pm 0.4 \quad 1.37 \pm 0.1$ & $1.40 \pm 0.5$ & $1.55 \pm 0.4$ & $1.64 \pm 0.5$ & $\begin{array}{lll}1.70 \pm 0.8 & 1.86 \pm 0.5\end{array}$ \\
\hline E. coli & $1.07 \pm 0.6 \quad 1.08 \pm 0.6$ & $1.09 \pm 0.1$ & $1.17 \pm 0.1$ & $1.23 \pm 0.1$ & $1.37 \pm 0.5 \quad 1.50 \pm 0.8$ \\
\hline E. afxogeness & $1.28 \pm 0.2 \quad 1.38 \pm 0.2$ & $1.44 \pm 0.3$ & $1.45 \pm 0.5$ & $1.52 \pm 0.4$ & $\begin{array}{lll}1.61 \pm 0.4 & 1.73 \pm 0.4\end{array}$ \\
\hline P. mirabilis & $\begin{array}{lll}1.24 \pm 0.3 & 1.24 \pm 0.2\end{array}$ & $1.26 \pm 0.1$ & $1.40 \pm 0.3$ & $1.57 \pm 0.1$ & $1.73 \pm 0.5 \quad 1.93 \pm 0.5$ \\
\hline C. splanolyticum & $1.16 \pm 0.5 \quad 1.20 \pm 0.3$ & $1.35 \pm 0.7$ & $1.34 \pm 0.6$ & $1.42 \pm 0.1$ & $1.50 \pm 0.3 \quad 1.52 \pm 0.4$ \\
\hline
\end{tabular}

*Mean and S.E of results as expressed units of turbidity (NTU)

*Table 5: In-vitro biodegradability potential of fungi isolates turbidity readings

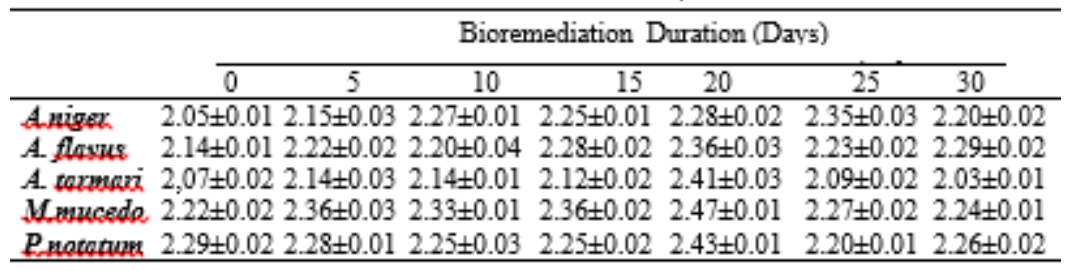

*Mean and S.E of results as expressed units of turbidity

The remediation efficiency (\%) of THC showed that the treatment consortium of $50 \mathrm{~g}$ of both poultry manure and phosphate rock had the highest remediation efficiency of $98.62 \%$ and the least was $38.56 \%$ obtained from the control. The principal component analyses biplot showing relationship between applied soil treatments and laboratory data accumulated during the study in figure 6 revealed that the consortium of both poultry manure and phosphate rock prove to be more effective than the single amendments of poultry manure and phosphate rock. The variables analyzed (phosphate, remediation efficiency, calcium, potassium, hydrocarbon utilizing bacteria and fungi) in figure 7 had positive influence in the enhancement of crude oil remediation, while other variables had negative influence which showed that phosphate played an important role in bioremediation of crude oil. Dendrogram from cluster analyses as grouped on the basis of soil treatments in figure 8 shows that phosphate rock and the consortium of both poultry manure and phosphate rock are most likely to present a similar effect in enhancing remediative capacities of the crude oil polluted soil than poultry manure.

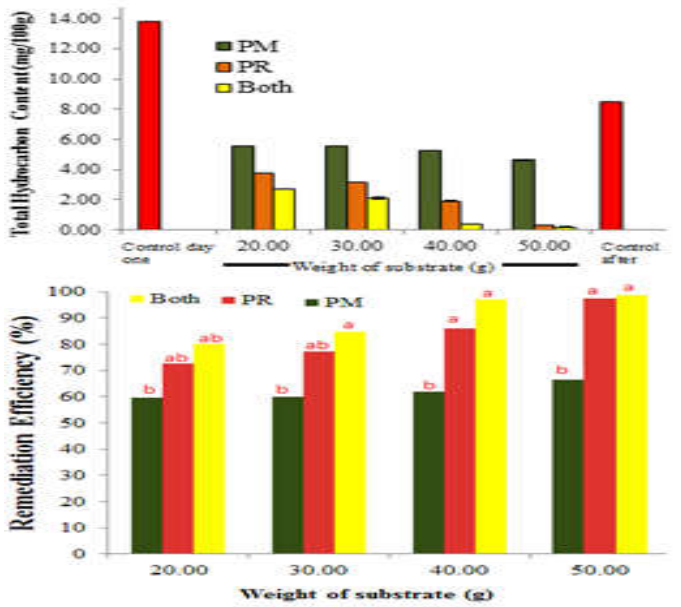

Fig 5: Effects of soil treatments on total hydrocarbon contents Keys: PM: contaminated soil amended with poultry manure; PR: contaminated soil amended with phosphate rock, both: contaminated soil amended with poultry manure and phosphate rock. 


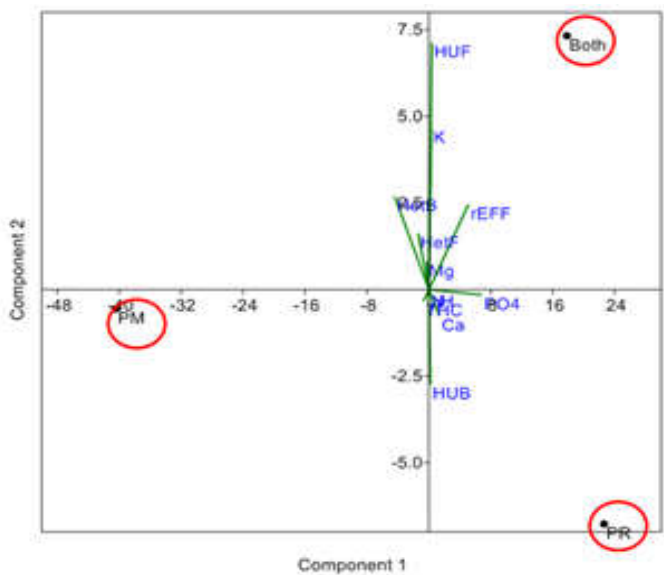

Fig 6: Principal component analyses biplot showing relationship between applied soil treatments and laboratory data accumulated during the study

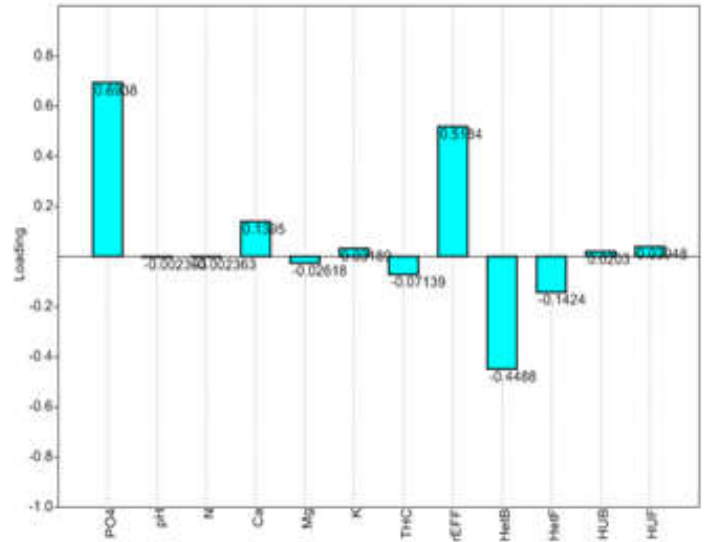

Fig 7: Loadings on the principal component anayses provided for laboratory data accumulated during the study

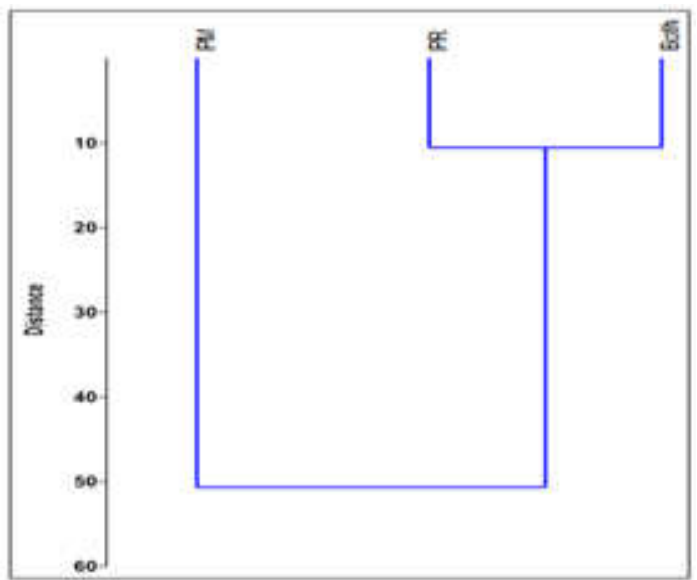

Fig 8: Dendrogram from cluster analyses of laboratory data accumulated during the study as grouped on the basis of soil treatments.

Furthermore, the correlations showed (table 6) a great relationship between phosphate and nitrogen, as well as the total hydrocarbon content and the remediation efficiency such that an increase in one of the listed parameter leads to decrease in the other.
Table 6: Correlations among the parameters determined during the study

\begin{tabular}{|c|c|c|c|c|c|c|c|c|c|c|c|}
\hline & P04 & $\mathrm{pH}$ & N & $\mathrm{Ca}$ & $\mathrm{Ng}_{\mathrm{g}}$ & K & IHC & $\mathbb{E E F F}$ & HetB HetF & & \\
\hline PO4 & 0 & 0.38 & 0.37976 & 0.068 & 0.355 & 0.797 & 0.06412 & 0.064182 & $0.075 \quad 0.14$ & 0.775 & 0.834 \\
\hline pH & -0.83 & 0 & $9.00 E-16$ & 0.448 & 0.734 & 0.417 & 0.31563 & 0.31558 & $0.554 \quad 0.52$ & 0.846 & 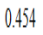 \\
\hline i & -0.83 & & 0 & 0.448 & 0.734 & 0.417 & 0.31563 & 0.31558 & 0.540 .522 & 0.846 & 0454 \\
\hline $\mathrm{Ca}$ & 0.994 & -0.76 & -0.76284 & 0 & 0.287 & 0.864 & 0.13197 & 0.13203 & $0.007 \quad 0.075$ & 0.707 & 0.902 \\
\hline $\mathrm{Mg}$ & -0.85 & 0.405 & 0.4051 & .09 & 0 & 0.849 & 0.41884 & 0.4189 & $0.28 \quad 0.212$ & 0.42 & 0.81 \\
\hline $\mathrm{K}$ & 0.314 & -0.79 & -0.7932 & 0.211 & 0.235 & 0 & 0.73246 & 0.7324 & 0.8710 .939 & 0.429 & 0.038 \\
\hline IHC & .0 .99 & 0.88 & 0.87959 & .098 & 0.791 & .0 .41 & 0 & $597 \mathrm{E}-05$ & 0.1390 .207 & 0.839 & 0.77 \\
\hline EEFF & 0.995 & -0.88 & .0 .87963 & 0.979 & .0 .79 & 0.408 & & 0 & 0.1390 .207 & 0.839 & 0.77 \\
\hline HetB & -0.99 & 0.756 & 0.75593 & .1 & 0.905 & .0 .2 & 0.97635 & -0.97633 & $\begin{array}{ll}0 & 0.068\end{array}$ & 0.7 & 0.909 \\
\hline HetF & -0.98 & 0.682 & 0.68205 & .099 & 0.945 & -0.1 & 0.94783 & -0.9478 & 0.994 & 0.632 & 0.977 \\
\hline HUB & 0.347 & 0.24 & 0.24019 & 0.444 & -0.79 & -0.78 & -0.2505 & 0.25045 & -0.45 & & 0.391 \\
\hline HUF & 0.258 & -0.76 & .0 .75593 & 0.153 & 0.292 & 0.998 & .03535 & 0.35355 & & & \\
\hline
\end{tabular}

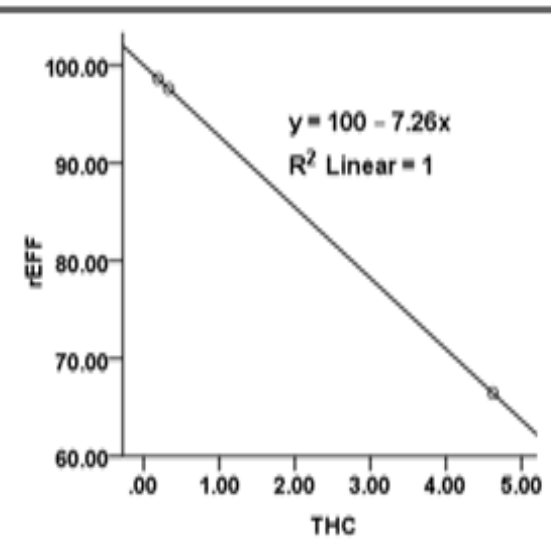

Fig 9: Regression model establishing the significant relationship between total hydrocarbon content (THC) (independent var.) and remediation efficiency (rEFF) (dependent var.) during the study

The regression model established significant relationship between total hydrocarbon content (THC) (independent var.) and remediation efficiency (rEFF) (dependent var.) (Figure 9), this suggests a perfect $(100 \%)$ association between THC and rEFF.

Conclusion: This study justifies that the use of soil amendments as joint application in bioremediation of crude oil polluted soil is better than single amendment application. Phosphate rock contributed immensely in the remediation of crude oil polluted soil when combined with poultry manure in providing robust nutrients requirement in promoting microbial growth for efficient and effective mineralization of crude oil in contaminated soil.

Acknowledgement: I acknowledge Nigerian Institute for Oil Palm Research (NIFOR) for providing the Phosphate Rock mineral and place for this experimental set up, University of Benin (UNIBEN) farm for providing the poultry manure and Environmental Biotechnology and Sustainability Research (EBSR) laboratory for providing the enabling environment for microbial and physiochemical analysis. 


\section{REFERENCES}

Adams, GO; Tawari-Fufeyin, P; Ehinomen, I (2014). Bioremediation of spent oil contaminated soils using poultry litter. Res. J. Eng. Appl. Sci. 3(2): 118 - 124

Ameh, AA; Kawo, AH (2017). Enumeration, isolation and identification of bacteria and fungi from soil contaminated with petroleum products using layer chicken droppings as an amendment. Bay. J. Pure. Appl. Sci. 10(1):219 - 225

American Public Health Association (APHA). (2008). Standard Methods for the Examination of Water and Waste Water. 21st ed. Washington DC. 16-25pp x

Ataikiru, TL; Okorhi-Damisa, BF; Akpaiboh, JI (2017). Microbial community structure of an oil polluted site in Effurun, Nigeria. Int. Res. J. Public. Environ. Health 4(3): 41 - 47.

Banat, MI. (2004), Microbial biodegradation. Microbiol. J. 53: $61-66$

Bujang, M; Ibrahim, NA; Rak, A (2013). Biodegradation of Oily Wastewater by Pure Culture of Bacillus cereus. J. Agric. Biological Sci. 8(2): 108-115

Chien, SH (1977). Thermodynamic considerations on the solubility of phosphate rock. Soil Sci. 123:117-121.

Chien, SH; Prochnow, LI; Mikkelsen, R (2010). Agronomic use of phosphate rock for direct application. Bett.Crops. 94(4): 21- 23.

Chikere, CB; Ekwuabu, CB (2014).Culture-dependent characterization of hydrocarbon utilizing bacteria in selected crude oil-impacted sites in Bodo, Ogoniland, Niger Delta, Nigeria. Afr. J. Environ. Sci. Biotech. 8(6): 401 - 406.

Chikere, CB; Okpokwasili, GC; Chikere, BO (2009). Bacterial diversity in a tropical crude oil-polluted soil undergoing bioremediation. Afr. J. Biotechnol. 8(11): 2535-2540.

Ezekoye, CC; Amakoromo, ER; Ibiene, AA (2017). Laboratory - Based Bioremediation of Hydrocarbon Polluted Mangrove Swamp Soil in the Niger Delta Using Poultry Wastes. Microbiol. Res. J. Int. 19(2): $1-14$.

Gulati, D; Mehta. S (2017). Isolation and identification of petrol degrading microorganisms from contaminated soil and comparison of their bioremediation potential. Intern. Res. J. Pharm. 8(2): $34-38$.

Head, IM; Jones, DM; Larter, SR (2003). Biological activity in the deep subsurface and the origin of heavy oil. Nat. 426: 344-352.
Ikhajiagbe, B; Anoliefo, GO; Omoregbee, O; Osigbemhe, P; (2014). Changes in the Intrinsic Qualities of a Naturally Attenuated Waste Engine Oil Polluted Soil after Exposure to Different Periods of Heat Shock. Res. Environ. 4(1): 45-53.

Kvenvolden, KA; Cooper, CK (2003). Natural seepage of crude oil into the marine environment. Geo-Mar. Lett. 23: 140-146.

Margesin, R; Zimmerbauer, A; Schinner, F (2000). Monitoring of bioremediation by soil biological activities. Chemos. 40: 339- 343.

Mugwira, L; Nyamangara, J; Hikwa, D (2002). Effect of manure and fertilizer on maize at a research station and in a smallholder (peasant) area of Zimbabwe. Plant Soil. 33: $379-402$.

Nwadinigwe, AO; Onyeidu, EG (2012). Bioremediation of crude oil polluted soil using bacteria and poultry manure monitored through soybean productivity. Pol. J. Environ. Stud. 21(1): 171-176.

Obasi, NA; Eze, E; Anyanwu, DI; Okorie, UC (2013). Effects of organic manures on the physicochemical properties of crude oil polluted soils. Afr. J. Biochem. Res. 7(6): 67-75.

Okafor, UC; Orji, MU; Agu, KC; Awah, NS; Okeke, BC; Okafor, OI; Okoro, NCN; (2016). Bioremediation of crude oil-polluted soil using broiler-chicken droppings. J. Appl. Environ. Microbiol. 4(4): 7584.

Okoh, AI (2006). Biodegradation alternative in the cleanup of petroleum hydrocarbon pollutants. Academ. J. Biotech. Mol. Bio. Rev. 1(2): 38-50.

Oviasogie, FE; Oviasogie, PO (2014). Physicochemical properties and fungal dynamics of soils obtained from public, reclaimed and residential wastes dumpsites. Nigerian J. Agric. Food Environ. 10(3):57-63.

Vidali, M (2001). Bioremediation. An overview. Pure and Appl. Chem. 73(7): 1163-1172.

Wong, JWC; Fang, M; Zhao, Z; Xing, B; (2004). Effect of surfactants on solubilization and degradation of phenenthrene under thermophilic conditions. $J$. Environ. Qual. 33: 2015 - 2025. 